\title{
Effects of Omega-3 on Lipid and Liver Function Tests
}

\author{
Woo-Soon Choi \\ Department of Clinical Laboratory Science, Songho University, Hoengseong, Korea
}

\section{Omega-3가 지질과 간기능검사에 미치는 영향}

\author{
최우순 \\ 송호대학교 임상병리과
}

\begin{abstract}
Omega-3 unsaturated fatty acids, including eicosapentaenoic acid (EPA) and docosahexaenoic acid (DHA), are found in fish and fish oil. Recent studies have shown that omega- 3 fatty acids are effective in cancer, cardiovascular disease, immune system, cirrhosis, and nervous system disorders. In particular, omega-3 was also reported to help improve hyperlipidemia and liver function tests. On the other hand, there are few cases in Korea. This study examined whether omega-3 is effective in improving hyperlipemia and liver function by taking $1 \mathrm{gm} /$ day for 2 weeks. As a result, AST was decreased in the liver function test, and GGT related to alcoholic hepatitis and fatty liver showed significant results. Omega-3 has been shown to help improve the liver function. The triglyceride, total cholesterol, and low density cholesterol associated with cardiovascular disease decreased after omega-3 ingestion, particularly high density cholesterol. Omega-3 has also been shown to improve the hyperlipidemia. Comparisons between males and females before and after the ingestion of omega-3 showed significant results in AST $(P<0.01)$ from the male group and in GGT $(P<0.01)$ and high density cholesterol $(P<0.01)$ from the female group. As a result, omega-3 intake can help control and improve liver function and hyperlipidemia.
\end{abstract}

Key words: Gamma-glutamyl transferase, High density lipoprotein cholesterol, Omega-3

This is an Open Access article distributed under the terms of the Creative Commons Attribution Non-Commercial License (http://creativecommons.org/licenses/by-nc/4.0) which permits unrestricted non-commercial use, distribution, and reproduction in any medium, provided the original work is properly cited.

Copyright (C) 2018 The Korean Society for Clinical Laboratory Science. All rights reserved.
Corresponding author: Woo-Soon Choi Department of Clinical Laboratory Science, Songho University, 210 Namsan-ro, Hoengseong 25242, Korea Tel: 82-33-340-1141 Fax: 82-33-340-1127 E-mail: woojung211@songho.ac.kr

Received: February 18, 2018 Revised $1^{\text {st. }}$ : March 2, 2018

Revised 2 ${ }^{\text {nd }}$ : March 8, 2018 Accepted: March 8, 2018

\section{서 론}

오메가-3 (n- $\omega 3$ fatty acid)인 알파 리놀렌산(alphalinolenic acid, ALA)은 오메가-6 (nw 6 fatty acid)인 리놀렌산 (linolenic acid, LA)과 함께 주요 불포화 지방산(polyunsaturated fatty acids, PUFAs)의 한 종류이다. 필수 불포화 지방 산은 생체 내에서는 합성되지 않으며 식이를 통해서 섭취해야 한다[1].

식이를 통해 섭취된 필수 지방산은 불포화과정(desaturation)과 신장과정(elongation)을 거쳐서 아라키돈산(arachnoid acid, AA)인 오메가-6 지방산과 에이코사펜타엔산(eicosa- pentanoic acid, EPA)인 오메가-3 지방산으로 바뀌며, 특히 에 이코사펜타엔산(EPA)은 대사를 거쳐서 도코사헥사엔산(docosahexanoic aicd, DHA)으로도 변형된다. 아라키돈산(AA), 에 이코사펜타엔산 $(\mathrm{EPA})$ 및 도코사헥사엔산 $(\mathrm{DHA})$ 을 긴 사슬 다 가 불포화 지방산(long chain polyunsaturated fatty acids, LC-PUFAs)이라고 부른다. 섭취 시 오메가-3와 오메가-6의 비 율의 균형이 중요하며, 현대인이 즐기는 서양식에는 오메가-3 보다는 오메가-6의 비율이 높은 편이어서 일반적인 식이 생활 상, 오메가-3를 충분하게 섭취를 못하는 경우가 많다[2, 3].

체내 오메가-6의 비율이 높아지면 세포막 성분의 변화가 나 타나며, 염증성 매개물질의 생산이 증가한다. 이는 오메가-6가 
세포막에서 프로스타글란딘(prostaglandin), 트롬복산(thromboxanes)과 같은 염증성 아이코사노이드(eicosanoids)의 전 구체인 아라키돈산(AA)으로 작용하기 때문이다. 반면 오메가-3 는 항염증 작용을 하는 것으로 알려져 있으며, 오메가-3의 비율 이 높은 식이를 하면 중추신경계의 세포막의 유동성(fluidity)과 인지질(phospholipid) 구성 비율이 변화되어 단백질의 구조와 기능이 변화될 수 있다[4].

오메가-3는 간에서 중성지방 및 저밀도지질단백질 합성을 억제함으로써 중성지방의 수치를 낮추는 효과가 높은 것으로 나타났으며. 미국심장학회의 기준에 의하면, 심혈관 질환이 없 는 경우에 동, 식물성 오메가 3 지방산의 섭취는 음식에 의해 충 분하며, 생선의 경우 1 주일에 2 번 이상을 섭취하면 충분한 것으 로 권장하고 있다. GISSI-Prevention 연구결과를 근간으로 하 여 심혈관 질환이 있는 환자들에게는 하루 $1 \mathrm{gm}$ 의 복용이 권장 된다[5, 6].

1 일 복용량에 대하여 저용량의 에이코사펜타엔산(EPA) 및 도코사헥사엔산(DHA)을 1 일 $400 \mathrm{mg}$ 섭취 또는 식물성 형태인 ALA 등의 투여가 심근경색 경력이 있던 환자들에게서 효과가 없는 것으로 보고되기도 하였으며. 다른 오메가 연구에서도 같 은 결과를 보여 $1 \mathrm{gm}$ 이하의 섭취량은 심혈관 질환의 예방효과 가 나타나지 않는 것으로 보고되었다[7, 8].

에이코사펜타엔산(EPA) 및 도코사헥사엔산(DHA)을 비롯한 생물학적으로 중요한 오메가-3 불포화 지방산은 어류 및 어유 에 많이 존재하며, 최근 연구에 따르면 오메가-3 지방산이 암, 심장 혈관 질환, 면역 체계, 간경변 및 신경계 장애에 유익한 효 과를 나타낼 수 있으며, 오메가-3 필수 지방산은 산화 스트레스 를 줄이고 활성 산소 종(reactive oxygen species, ROS)의 생성 을 방지함으로써 항산화 특성을 갖고 있으며, 고지혈증과 관련 된 환자에서 혈청 지질 및 간 효소 개선에있어서 오메가-3의 효 능이 보고되어지고 있다[9-13].

본 연구는 외국의 경우 오메가-3에 대한 연구가 활발하지만 [14-16] 우리나라의 경우 쥐를 대상으로 하거나 식물에서의 오 메가-3의작용에 대한 연구에 한정되어 있어 오메가-3가 인체에 어떤 변화가 있는지 알아보고자 하였으며, 특히 고지혈증과간기 능 개선에 도움이 된다고 하여 많은 사람들이 건강식품으로 복용 하고 있어 얼마나 개선에 도움을 주는지 확인하고자 하였다.

\section{재료 및 방법}

\section{1. 연구대상}

연구 대상은 2016년 10월부터 11월까지 대학생을 대상으로
하였다. 연구 대상의 채택 기준은 질환이 있어 약을 복용하는 경 우는 제외하였으며, 실험기간 중 음주, 야식 등을 절제하도록 하 였으며, 모든 대상자에게 서면동의서를 받았고, 충분한 설명 후 실험을 진행하였다. 대상자는 남자 16 명, 여자 21명 총 37 명으 로 평균 연령은 21세이었다.

\section{2. 연구방법}

건강보조식품 오메가-3 1,000 mg을 섭취 전과 2주간 섭취 후를 측정하였다. 대상자에게는 매일 아침 식후 $1,000 \mathrm{mg}$ (캡 슐)을 2 주간 섭취하도록 하였다. 검사를 위한 채혈은 실험 전 8 시간 공복 후 채혈하였고, 2 주 후 공복시 채혈하였다. 검사종목 은 혈당(glucose), aspatate transferase (AST), alanine transferase (ALT), gamma-glutamyl transferase (GGT), 총콜레스 테롤(total cholesterol, T-Cho), 중성지방(triglyceride, TG), 고밀도 콜레스테롤(HDL-Cholesterol), 저밀도 콜레스테롤 (LDL-Cholesterol)를 측정하였다. 검사진행은 공복 시 혈액을 SST (serum separate tube)에 $5 \mathrm{~mL}$ 채혈하여 1시간 방치 후 $3,000 \mathrm{rpm}$ 에서 10분간 원심분리기(Labogene 1580R, BMS, Daejoen, Korea)로 상층액을 분리하였다. 분리한 상층액을 생 화학 자동분석장치(Respons 920, Diagnostic Systems GmbH, Holzheim, Germany)를 이용하여 자동분석검사를 시행하였다.

\section{3. 통계분석}

통계분석은 대응표본 T검정(paired t-test)을 이용하였다 (SPSS PASW Statistics 18.0, SPSS, Chicago, US). 오메가-3의 섭취 전과 섭취 후를 $P$-value를 통하여 비교 분석하였고, 유의 성은 0.05 이하를 유의한 결과로 판정하였다. 그래프는 오차막

Table 1. Comparison of Omega-3 before and after intake in biochemistry test $(\mathrm{N}=37)$

\begin{tabular}{|c|c|c|c|}
\hline \multirow{2}{*}{ Variable } & \multicolumn{2}{|c|}{ Mean \pm SD } & \multirow{2}{*}{$P$-value } \\
\hline & Before & After & \\
\hline Glucose (mg/dL) & $90.6 \pm 11.38$ & $92.3 \pm 7.78$ & 0.190 \\
\hline AST (IU/L) & $20.5 \pm 9.03$ & $19.5 \pm 6.21$ & 0.177 \\
\hline ALT (IU/L) & $24.0 \pm 27.55$ & $27.7 \pm 29.85$ & 0.180 \\
\hline GGT (IU/L) & $28.5 \pm 22.97$ & $27.3 \pm 22.46$ & $0.020^{*}$ \\
\hline TG (mg/dL) & $93.9 \pm 46.86$ & $89.4 \pm 27.28$ & 0.362 \\
\hline T-Cho (mg/dL) & $181.1 \pm 30.19$ & $180.6 \pm 31.12$ & 0.847 \\
\hline $\mathrm{HDL}-\mathrm{C}(\mathrm{mg} / \mathrm{dL})$ & $61.3 \pm 12.80$ & $64.6 \pm 14.41$ & $0.027^{*}$ \\
\hline LDL-C (mg/dL) & $101.8 \pm 24.08$ & $98.2 \pm 22.86$ & 0.072 \\
\hline
\end{tabular}

Abbreviations: AST, aspartate aminotransferase; ALT, alanine aminotransferase; GGT, gamma-glutamyl transpeptidase; T-Cho, total cholesterol; TG, triglyceride; HDL-C, High density lipoprotein cholesterol; LDL-C, Low density lipoprotein cholesterol. $\star p<0.05$ : significance. 

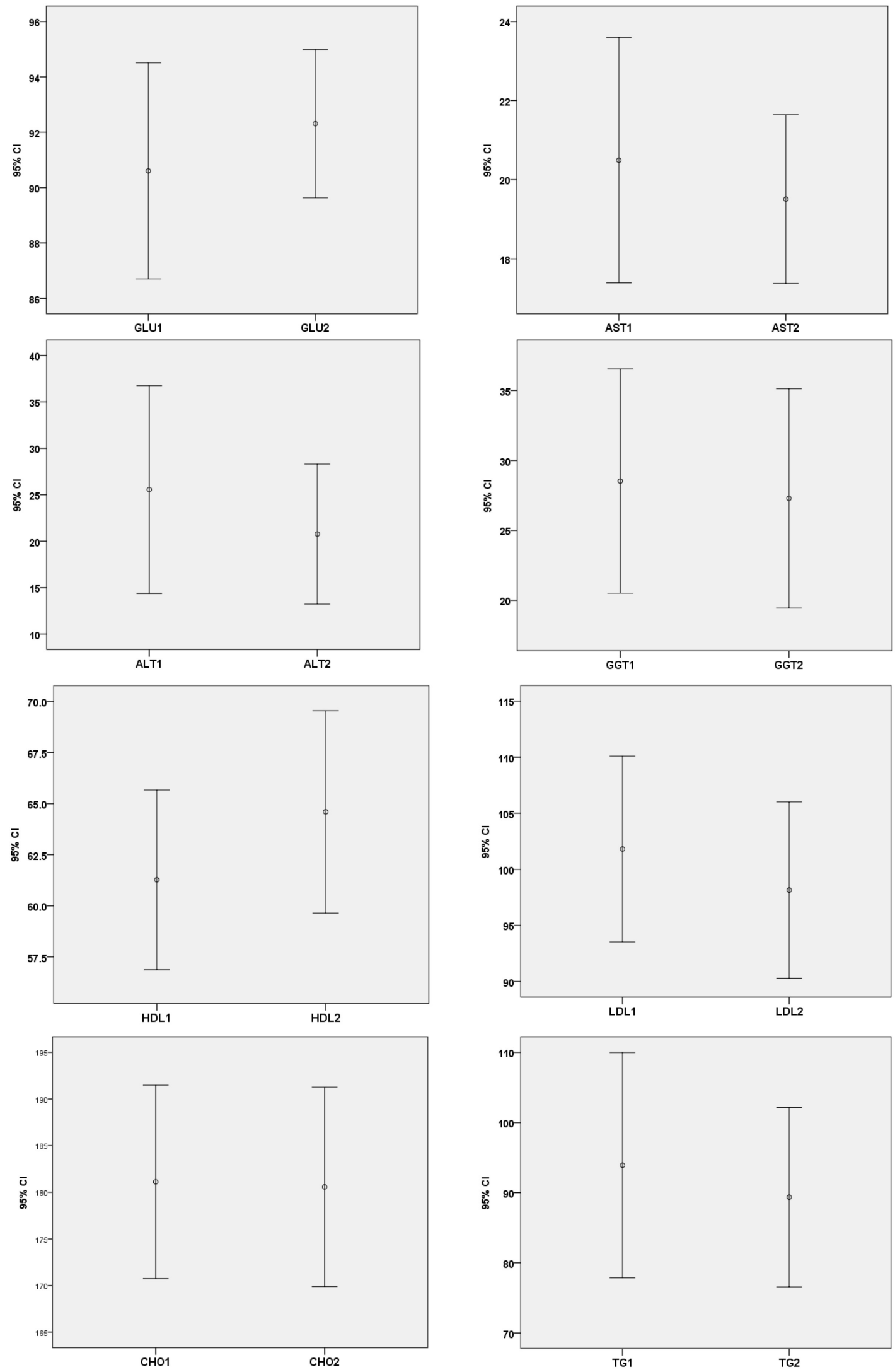

Figure 1. This graph shows the distribution before and after omega-3 intake. The results of pre-omega-3 intake of GLU1, AST1, ALT1, GGT1 HDL1, LDL1, CHO1 and TG1. GLU2, AST2, ALT2, GGT2, HDL2, LDL2, CHO2 and TG2 are the results after intake. 
대의 개인변수값으로 측정하였다.

\section{결 과}

\section{1. 오메가-3 섭취 전과 섭취 후 비교}

오메가-3 섭취 전과 2주 동안 섭취 후 결과에서 공복혈당은 섭취 전 $90.6 \pm 11.38 \mathrm{mg} / \mathrm{dL}$, 섭취 후 $92.3 \pm 7.78 \mathrm{mg} / \mathrm{dL}$ 로 섭 취 후가 높게 나타났다 $(P=0.190)$. AST는 섭취 전 $20.5 \pm 9.03$ $\mathrm{IU} / \mathrm{L}$, 섭취 후 $19.5 \pm 6.21 \mathrm{IU} / \mathrm{L}$ 로 나타났으며, ALT는 섭취 전 $24.0 \pm 27.55 \mathrm{IU} / \mathrm{L}$, 섭취 후 $27.7 \pm 29.85 \mathrm{IU} / \mathrm{L}$ 결과로 AST는 섭취 후 감소하였고 ALT는 증가하였다. GGT는 섭취 전 $28.5 \pm 22.97 \mathrm{IU} / \mathrm{L}$, 섭취 후 $27.3 \pm 22.46 \mathrm{IU} / \mathrm{L}$ 로 섭취 후 감소 하였고 유의성을 보였다 $(P<0.05)$. 중성지방은 섭취 전 $93.9 \pm 46.86 \mathrm{mg} / \mathrm{dL}$, 섭취 후 $89.4 \pm 27.28 \mathrm{mg} / \mathrm{dL}$, 총콜레스 테롤은 섭취 전 $181.1 \pm 30.19 \mathrm{mg} / \mathrm{dL}$, 섭취 후 $180.6 \pm 31.12$ $\mathrm{mg} / \mathrm{dL}$ 로 섭취 후 감소를 보였으나 통계적으로 유의성을 보이 지 않았다. 고밀도 콜레스테롤은 섭취 전 $61.3 \pm 12.80 \mathrm{mg} / \mathrm{dL}$, 섭취 후 $64.6 \pm 14.41 \mathrm{mg} / \mathrm{dL}$ 로 섭취 후 증가하였으며 유의성을 나타냈다 $(P<0.05)$. 저밀도 콜레스테롤은 섭취전 $101.8 \pm 24.08$ $\mathrm{mg} / \mathrm{dL}$ 섭취 후 $98.2 \pm 22.86 \mathrm{mg} / \mathrm{dL}$ 로 섭취 후감소하였다. 결 과적으로 GGT와 고밀도 콜레스테롤은 유의성을 보였고, 저밀 도 콜레스텔롤은 통계적으로 유의성을 나타내지 않았지만 유의 성에 가까운 결과를 보였다(Table 1, Figure 1).

\section{2. 남자군과 여자군의 오메가-3 섭취 전과 섭취 후 비교 결과}

오메가-3 섭취 전과 섭취 후 결과에서 공복혈당에서 남자군 섭취 전 $88.0 \pm 9.77 \mathrm{mg} / \mathrm{dL}$, 섭취 후 $91.2 \pm 4.68 \mathrm{mg} / \mathrm{dL}$, 여자 군은 섭취전 $92.3 \pm 11.60 \mathrm{mg} / \mathrm{dL}$, 섭취 후 $93.1 \pm 9.20 \mathrm{mg} / \mathrm{dL}$ 의 결과를 보였다. AST는 남자군이 섭취 전 $24.2 \pm 11.09 \mathrm{IU} / \mathrm{L}$, 섭취 후 $21.4 \pm 7.50 \mathrm{IU} / \mathrm{L}$, 여자군이 섭취 전 $17.4 \pm 5.01 \mathrm{IU} / \mathrm{L}$, 섭취후 $13.2 \pm 5.43 \mathrm{IU} / \mathrm{L}$ 로 남자군에서 유의성을 나타냈다 $(P<$ $0.05)$. ALT는 남자군에서 섭취 전 $31.7 \pm 38.19 \mathrm{IU} / \mathrm{L}$, 섭취 후 $29.8 \pm 29.94 \mathrm{IU} / \mathrm{L}$, 여자군에서 섭취 전 $19.4 \pm 25.20 \mathrm{IU} / \mathrm{L}$, 섭 취 후 $27.7 \pm 29.85 \mathrm{IU} / \mathrm{L}$ 로 나타났다. GGT는 남자군에서 섭취 전 $38.8 \pm 28.46 \mathrm{IU} / \mathrm{L}$, 섭취 후 $37.9 \pm 27.05 \mathrm{IU} / \mathrm{L}$, 여자군에서 섭취 전 $19.33 \pm 10.33 \mathrm{IU} / \mathrm{L}$, 섭취 후 $17.9 \pm 10.89 \mathrm{IU} / \mathrm{L}$ 로 나타 나 모두 감소하였고, 특히 여자군은 유의한 결과를 보였다 $(P<$ 0.05). 중성지방은 남자군에서 섭취 전 $98.5 \pm 50.55 \mathrm{mg} / \mathrm{dL}$, 섭 취 후 $99.6 \pm 47.86 \mathrm{mg} / \mathrm{dL}$, 여자군에서 섭취 전 $87.4 \pm 41.66$ $\mathrm{mg} / \mathrm{dL}$, 섭취 후 $79.7 \pm 22.16 \mathrm{mg} / \mathrm{dL}$ 로 나타났으며, 총콜레스 테롤은 남자군에서 섭취 전 $185.8 \pm 32.82 \mathrm{mg} / \mathrm{dL}$, 섭취 후 $184.4 \pm 29.68 \mathrm{mg} / \mathrm{dL}$, 여자군에서 섭취 전 $173.5 \pm 28.01$ $\mathrm{mg} / \mathrm{dL}$, 섭취 후 $173.8 \pm 31.65 \mathrm{mg} / \mathrm{dL}$ 의 결과를 보였다. 고밀 도 콜레스테롤은 남자군에서 섭취 전 $60.2 \pm 13.44 \mathrm{mg} / \mathrm{dL}$, 섭 취 후 $62.8 \pm 12.62 \mathrm{mg} / \mathrm{dL}$, 여자군에서 섭취 전 $62.0 \pm 12.07$ $\mathrm{mg} / \mathrm{dL}$, 섭취 후 $66.1 \pm 16.03 \mathrm{mg} / \mathrm{dL}$ 로 여자군에서 유의성을 보였다 $(P<0.05)$. 저밀도콜레스테롤은 남자군에서 섭취 전

Table 2. Comparison of man $(\mathrm{N}=16)$ and woman $(\mathrm{N}=21)$ in biochemistry test

\begin{tabular}{|c|c|c|c|c|}
\hline \multirow{2}{*}{ Variable } & \multirow{2}{*}{ Man and Woman } & \multicolumn{2}{|c|}{ Mean \pm SD } & \multirow{2}{*}{$P$-value } \\
\hline & & Before & After & \\
\hline \multirow[t]{2}{*}{ Glucose (mg/dL) } & Man & $88.0 \pm 9.77$ & $91.2 \pm 4.68$ & 0.180 \\
\hline & Woman & $92.3 \pm 11.60$ & $93.1 \pm 9.20$ & 0.662 \\
\hline \multirow[t]{2}{*}{ AST (IU/L) } & Man & $24.2 \pm 11.09$ & $21.4 \pm 7.50$ & $0.047^{\star}$ \\
\hline & Woman & $17.4 \pm 5.01$ & $17.7 \pm 4.11$ & 0.431 \\
\hline \multirow[t]{2}{*}{ ALT (IU/L) } & Man & $31.7 \pm 38.19$ & $29.8 \pm 29.94$ & 0.447 \\
\hline & Woman & $19.4 \pm 25.20$ & $13.2 \pm 5.43$ & 0.265 \\
\hline \multirow[t]{2}{*}{ GGT (IU/L) } & Man & $38.8 \pm 28.46$ & $37.9 \pm 27.05$ & 0.321 \\
\hline & Woman & $19.33 \pm 10.33$ & $17.9 \pm 10.89$ & $0.012^{*}$ \\
\hline \multirow[t]{2}{*}{ TG (mg/dL) } & Man & $98.5 \pm 50.55$ & $99.6 \pm 47.86$ & 0.879 \\
\hline & Woman & $87.4 \pm 41.66$ & $79.7 \pm 22.16$ & 0.208 \\
\hline \multirow[t]{2}{*}{ T-Cho (mg/dL) } & Man & $185.8 \pm 32.82$ & $184.4 \pm 29.68$ & 0.726 \\
\hline & Woman & $173.5 \pm 28.01$ & $173.8 \pm 31.65$ & 0.894 \\
\hline \multirow[t]{2}{*}{$\mathrm{HDL}-\mathrm{C}(\mathrm{mg} / \mathrm{dL})$} & Man & $60.2 \pm 13.44$ & $62.8 \pm 12.62$ & 0.185 \\
\hline & Woman & $62.0 \pm 12.07$ & $66.1 \pm 16.03$ & $0.050^{*}$ \\
\hline \multirow[t]{2}{*}{$\mathrm{LDL}-\mathrm{C}(\mathrm{mg} / \mathrm{dL})$} & Man & $105.1 \pm 26.41$ & $101.9 \pm 23.0$ & 0.319 \\
\hline & Woman & $96.8 \pm 22.68$ & $93.2 \pm 22.45$ & 0.166 \\
\hline
\end{tabular}

Abbreviations: See Table 1.

$\star p<0.05$ : significance. 
$105.1 \pm 26.41 \mathrm{mg} / \mathrm{dL}$ 섭취 후 $101.9 \pm 23.0 \mathrm{mg} / \mathrm{dL}$ 여자군에 서 섭취 전 $96.8 \pm 22.68 \mathrm{mg} / \mathrm{dL}$ 섭취 후 $93.2 \pm 22.45 \mathrm{mg} / \mathrm{dL}$ 로 나타났다. 결과적으로 남자군 AST와 여자군에서 GGT와 고밀 도 콜레스테롤이 유의성을 보였다(Table 2).

\section{고 찰}

최근 경제수준의 향상으로 건강과 질병에 대한 관심이 증가함 에 따라 건강기능식품의 이용이 증가하고 있다. 오메가-3도 많 은 사람들이 건강식품으로 이용하고 있으며, 고지혈증 개선과 간기능검사에 도움을 주는 것으로 보고되고 있다[17]. 오메가-3 지방산은 에이코사펜타엔산 $(\mathrm{EPA})$ 및 도코사헥사엔산(DHA)으 로서 어류 등의 등푸른 생선과 바닷물범, 해조류등이 주요 공급 원이 된다[18]. 오메가-3 지방산은 우리 몸에서 합성되지 않기 때문에 식이를 통하여 섭취해야하는 필수 지방산으로서, 혈중 중성지질 개선 및 혈행 개선을 통하여 심뇌혈관질환의 발생 감 소에 영향을 미친다고 보고되고 있다[19]. 오메가-3 지방산 함 유 유지의 기준규격은 에이코사펜타엔산(EPA) 및 도코사헥사 엔산(DHA)의 합으로서 식용 가능한 어류 유래 원료는 180 $\mathrm{mg} / \mathrm{g}$ 이상, 바닷물범 유래 원료는 $120 \mathrm{mg} / \mathrm{g}$ 이상, 조류 유래 원 료는 $300 \mathrm{mg} / \mathrm{g}$ 이상 함유되어 있어야 한다. 또한, 오메가-3 지 방산 함유 유지의 일일섭취량은 에이코사펜타엔산(EPA) 및 도 코사헥사엔산(DHA)의 합으로서 $0.5 \sim 2 \mathrm{~g} / \mathrm{day}$ 으로 보고하고 있다[20,21]. 본 실험에서는 건강기능식품인 오메가-3를 2주 간 일일섭취량 기준범위인 $1 \mathrm{gm}$ 을 섭취하여 혈중 지질 개선과 간기능 개선에 효과가 있는지 알아보고자 하였다.

간기능검사항목인 AST와 ALT에서 Atakisi 등[12]의 $500 \mathrm{mg}$ 을 7일간 섭취 후 감소하였다고 하였고, Zhu 등[13]은 $2 \mathrm{gm}$ 을 7주간 섭취하도록 한 결과와는 AST, ALT, GGT 모두 유의하게 감소하였다고 하였다. 본 결과에서 AST는 섭취 전 $20.5 \pm 9.03$ $\mathrm{IU} / \mathrm{L}$, 섭취 후 $19.5 \pm 6.21 \mathrm{IU} / \mathrm{L}$ 로 미미하게 감소한 것으로 나타 났으나, ALT는 섭취 전 $24.0 \pm 27.55 \mathrm{IU} / \mathrm{L}$, 섭취 후 $27.7 \pm 29.85$ $\mathrm{IU} / \mathrm{L}$ 로 약간 증가한 결과로 상반된 결과를 보였다. 이는 섭취기 간이 짧고 학생들의 식이와 관계가 있으리라 생각된다. GGT는 섭취 전 $28.5 \pm 22.97 \mathrm{IU} / \mathrm{L}$, 섭취 후 $27.3 \pm 22.46 \mathrm{IU} / \mathrm{L}$ 로 섭취 후감소하였고, 유의성을 보여 $(P<0.05)$ 매우 일치한 결과를 나 타냈다. 결과적으로 간기능검사에서는 알콜성간염이나 지방간 과 관계있는 GGT에서 유의한 결과로 보여 간기능검사에 도움 을 주는 것으로 나타났다. 고지혈증과 관계있는 검사에서 Zhu 등[13]은 오메가-3 섭취군에서 중성지방, 총콜레스테롤, 고밀 도 콜레스테롤, 저밀도 콜레스테롤도 유의한 결과를 보였고,
Bruin 등[16]은 중성지방에서 유의성을 보였으며, Stroes 등 [22]은 TG, 저밀도 콜레스테롤에서 유의성을 보였다고 하였다. 본 결과에서 중성지방은 섭취 전 $93.9 \pm 46.86 \mathrm{mg} / \mathrm{dL}$, 섭취 후 $89.4 \pm 27.28 \mathrm{mg} / \mathrm{dL}$, 총콜레스테롤은 섭취 전 $181.1 \pm 30.19$ $\mathrm{mg} / \mathrm{dL}$, 섭취 후 $180.6 \pm 31.12 \mathrm{mg} / \mathrm{dL}$, 저밀도 콜레스테롤은 섭취 전 $101.8 \pm 24.08 \mathrm{mg} / \mathrm{dL}$ 섭취 후 $98.2 \pm 22.86 \mathrm{mg} / \mathrm{dL}$ 로 통계적으로 유의성을 보이지 않았지만 모두 감소를 보여 고지 혈증 개선에 도움을 주는 것으로 나타났다. 좋은 콜레스테롤인 고밀도 콜레스테롤은 섭취 전 $61.3 \pm 12.80 \mathrm{mg} / \mathrm{dL}$, 섭취 후 $64.6 \pm 14.41 \mathrm{mg} / \mathrm{dL}$ 로 섭취 후 증가하였으며 유의성을 보였다 $(P<0.05)$. Zhu 등[13]과 Bruin 등[16] 그리고 Stroes 등[22]에 서 고밀도 콜레스테롤이 유의하게 증가하였다는 결과와 일치하 여 고지혈증 예방에 도움을 주는 것으로 나타났다.

남자군과 여자군별 오메가-3 섭취전과 섭취후의 비교결과

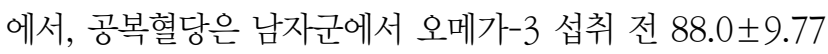
$\mathrm{mg} / \mathrm{dL}$, 섭취 후 $91.2 \pm 4.68 \mathrm{mg} / \mathrm{dL}$, 여자군은 섭취 전 $92.3 \pm$ $11.60 \mathrm{mg} / \mathrm{dL}$, 섭취 후 $93.1 \pm 9.20 \mathrm{mg} / \mathrm{dL}$ 의 결과를 보여 혈당 개선에는 영향을 주지 않는 것으로 나타났다. AST는 남자군이 섭취 전 $24.2 \pm 11.09 \mathrm{IU} / \mathrm{L}$, 섭취 후 $21.4 \pm 7.50 \mathrm{IU} / \mathrm{L}$ 로 여자군 이 섭취 전 $17.4 \pm 5.01 \mathrm{IU} / \mathrm{L}$, 섭취 후 $13.2 \pm 5.43 \mathrm{IU} / \mathrm{L}$ 로 남자 군에서 유의성을 나타내 $(P<0.05)$ 간기능 개선에 도움을 주는 것으로 나타났다. ALT는 남자군에서 섭취 전 $31.7 \pm 38.19$ $\mathrm{IU} / \mathrm{L}$, 섭취 후 $29.8 \pm 29.94 \mathrm{IU} / \mathrm{L}$, 여자군에서 섭취 전 $19.4 \pm$ $25.20 \mathrm{IU} / \mathrm{L}$, 섭취 후 $27.7 \pm 29.85 \mathrm{IU} / \mathrm{L}$ 로 나타나 남자군에서 감소를 보여 간기능에 도움을 주는 것으로 나타났으나, 여자군 에서는 증가하여 식습관이 영향을 준 것으로 생각되 이에 대한 추가적인 연구가 필요하리라 생각된다. GGT는 남자군에서 오 메가-3 섭취 전 $38.8 \pm 28.46 \mathrm{IU} / \mathrm{L}$, 섭취 후 $37.9 \pm 27.05 \mathrm{IU} / \mathrm{L}$, 여자군에서 섭취 전 $19.33 \pm 10.33 \mathrm{IU} / \mathrm{L}$, 섭취 후 $17.9 \pm 10.89$ $\mathrm{IU} / \mathrm{L}$ 로 나타나 남자군과 여자군에서 모두 감소하였고, 특히 여 자군에서 유의성을 보여 $(P<0.05)$ 간기능검사에 도움을 주는 것으로 나타났다. 중성지방은 남자군에서 섭취 전 $98.5 \pm 50.55$ $\mathrm{mg} / \mathrm{dL}$, 섭취 후 $99.6 \pm 47.86 \mathrm{mg} / \mathrm{dL}$, 여자군에서 섭취 전 $87.4 \pm 41.66 \mathrm{mg} / \mathrm{dL}$, 섭취 후 $79.7 \pm 22.16 \mathrm{mg} / \mathrm{dL}$ 로 나타나 남 자군에서는 변화가 없었지만, 여자군에서 감소하였다. 총콜레 스테롤은 남자군에서 섭취 전 $185.8 \pm 32.82 \mathrm{mg} / \mathrm{dL}$, 섭취 후 $184.4 \pm 29.68 \mathrm{mg} / \mathrm{dL}$, 여자군에서 섭취 전 $173.5 \pm 28.01$ $\mathrm{mg} / \mathrm{dL}$, 섭취 후 $173.8 \pm 31.65 \mathrm{mg} / \mathrm{dL}$ 의 결과를 보였다. 저밀 도 콜레스테롤은 남자군에서 오메가-3 섭취 전 $105.1 \pm 26.41$ $\mathrm{mg} / \mathrm{dL}$ 섭취 후 $101.9 \pm 23.0 \mathrm{mg} / \mathrm{dL}$ 로 여자군에서 섭취 전 $96.8 \pm 22.68 \mathrm{mg} / \mathrm{dL}$ 섭취 후 $93.2 \pm 22.45 \mathrm{mg} / \mathrm{dL}$ 로 나타났다. 
고밀도 콜레스테롤은 남자군에서 섭취 전 $60.2 \pm 13.44 \mathrm{mg} / \mathrm{dL}$, 섭취 후 $62.8 \pm 12.62 \mathrm{mg} / \mathrm{dL}$, 여자군에서 섭취 전 $62.0 \pm 12.07$ $\mathrm{mg} / \mathrm{dL}$, 섭취 후 $66.1 \pm 16.03 \mathrm{mg} / \mathrm{dL}$ 로 여자군에서 유의성을 보였다 $(P<0.05)$. 결과적으로 통계적 유의성을 보이지 않았지 만 중성지방과 고밀도 콜레스테롤이 감소하였고, 특히 고밀도 콜레스테롤에서 오메가-3 섭취군이 유의하게 증가하여 고지혈 증 개선에 도움을 주는 결과를 보였다.

본 결과에서 아쉬운점은 2주간의 짧은 기간으로 장기복용 시 영향과 오메가-3와 오메가-6의 비율에 대한 연구가 미흡한점 과 대상자가 대학생에게 한정되었다는 것이다. 앞으로 이에 대 한 보완이 이루어진다면 오메가-3의 복용으로 인한 건강한 생 활에 도움을 주는 연구가 되리라 생각된다.

\section{요 약}

에이코사펜타엔산(EPA) 및 도코사헥사엔산(DHA)을 비롯한 오메가-3 불포화 지방산은 어류 및 어유에 많이 존재한다. 최근 연구에 따르면 오메가-3 지방산이 암, 심장 혈관 질환, 면역 체 계, 간경변 및 신경계 장애에 효과가 있는 것으로 나타났다. 특 히, 오메가-3는 고지혈증 개선과 간기능검사에 도움을 주는 것 으로 보고되고 있다. 하지만 우리나라의 경우 사례가 많지 않다. 본 연구에서는 오메가-3를 2 주간 $1 \mathrm{gm} / \mathrm{day}$ 을 섭취하여 혈중 고지혈증과 간기능 개선에 효과가 있는지 알아보고자 하였다. 본 실험 결과, 간기능검사에서는 AST가 감소하였고, 알콜성간 염이나 지방간과 관계있는 GGT에서 유의한 결과를 보였다. 오 메가-3가 간기능 개선에 도움을 주는 것으로 나타났다. 심혈관 질환과 관계있는 중성지방, 총콜레스테롤, 저밀도 콜레스테롤 은 오메가-3 섭취후 감소를 보였고, 특히 고밀도 콜레스테롤이 유의하게 증가하였다. 고지혈 질환에서도 개선효과가 있는 것 으로 나타났다. 남자군과 여자군별 오메가-3 섭취 전과 후를 비 교한 결과, 남자군에서는 AST에서 유의한 결과를 보였고, 여자 군에서는 GGT와 고밀도 콜레스테롤에서 유의한 결과를 보였 다. 결과적으로 오메가-3 섭취가 간기능검사나 고지혈 질환의 예방 및 개선에 도움이 되는 것으로 나타났다.

\section{Acknowledgements: None \\ Conflict of interest: None}

\section{REFERENCES}

1. Raz R, Gabis L. Essential fatty acids and attention-deficit-hyperactivity disorder: a systematic review. Dev Med Child Neurol. 2009;51:580-592.

2. Hawkey E, Nigg JT. Omega-3 fatty acid and ADHD: blood level analysis and meta-analytic extension of supplementation trials. Clin Psychol Rev. 2014;34:496-505.

3. Simopoulos AP. Omega-3 fatty acids in health and disease and in growth and developmen. Am J Clin Nutr. 1991;54:438-463.

4. Simopoulos AP. Omega-3 fatty acids in inflammation and autoimmune diseases. J Am Coll Nutr. 2002;21:495-505.

5. Davidson MH. Mechanisms for the hypotriglyceridemic effect of marine omega-3 fatty acids. Am J Cardiol. 2006;98:27-33.

6. De CR. n-3 fatty acids in cardiovascular disease, N Engl J Med. 2011;364:2439-2450.

7. Gotto A, Pownall H. Manual of lipid disorders. 3rd ed. London: Lippincot and Williams; 2002.

8. Han KH. Omega-3-fatty acid and triglyceride. Korean J Med. 2012;83:724-727.

9. Hardman WE. (n-3) Fatty acids and cancer therapy. J Nutr. 2004;134:3427-3430.

10. Aronson WJ, Glaspy JA, Reddy ST, Reese D, Heber D, Bagga D. Modulation of omega-3/omega-6 polyunsaturated ratios with dietary fish oils in men with prostate cancer. Urology. 2001;58:283-288.

11. Rose DP, Connoly JM. Omega-3 fatty acids as cancer chemopreventive agents. Pharmacol Ther. 1999;83:217-244.

12. Atakisi O, Atakisi E, Ozcan A, Karapehlivan M, Kart A. European Review for Medical and Pharmacological Sciences Protective effect of omega-3 fatty acids on diethylnitrosamine toxicity in rats. European Review for Medical and Pharmacological Sciences. 2013;17:467-471.

13. Zhu FS, Liu S, Chen XM, Huang ZG, Zhang DW. Effects of $n-3$ polyunsaturated fatty acids from seal oils on nonalcoholic fatty liver disease associated with hyperlipidemia. World J Gastroenterol. 2008;14:6395-6400.

14. Hassan KS, Hassan SK, Hijazi EG, Khazim KO. Effects of omega-3 on lipid profile and inflammation markers in peritoneal dialysis patients. Ren Fail. 2010;32:1031-1035.

15. Soden JS, Lovell MA, Brown K, Partrick DA, Sokol RJ. Failure of resolution of portal fibrosis during omega-3 fatty acid lipid emulsion therapy in two patients with irreversible intestinal failure. J Pediatr. 2010;156:327-331.

16. Kris-Etherton PM, Harris WS, Appel LJ. Fish consumption, fish oil, omega-3 fatty acids, and cardiovascular disease. Am Heart Assoc. 2002;106:2747-2757.

17. Kim JY, Kim DB, Lee HJ. Regulation on health/ functional foods in Korea. Toxicology. 2006;221:112-118.

18. Kris-Etherton PM, Harris WS, Appel LJ. Fish consumption, fish oil, omega-3 fatty acids, and cardiovascular disease. Am Heart Assoc. 2002;106:2747-2757.

19. Cho KH, Park YM. Cardiovascular disease and health functional foods. Korean J Fam Med. 2010;31:587-594.

20. Ministry of Health and Welfare, Korea Health Industry Development Institute. Ministry of Health and Welfare, Korea Centers for Disease Control and Prevention. The 3rd Korea 
National Health and Nutrition Examination Survey (KNHANES III) [Internet]. Cheongju: Korea Centers for Disease Control and Prevention; 2018 [cited 2018 Mar 07]. Available from: https://knhanes. cdc.go.kr/knhanes/index.do.

21. Korean Nutrition Society. 2010 dietary reference intakes for Koreans [Internet]. Seoul: Korean Nutrition Society; 2018 [cited
2018 Mar 07]. Available from: http://www.kns.or.kr/ Download/2010KDRIs_open_final.pdf.

22. Stroes E, Bruin TD, Davidson M, Yang H, Kvarnstrom M, Lundstrom T. Omega-3 carboxylic acids in severe hypertriglyceridemia: EVOLVE II study results. Atherosclerosis. 2016;252:E232. 